\title{
Biomedical Research and the Commercial Exploitation of Human Tissue
}

\author{
STEPHEN WILKINSON
}

\begin{abstract}
There is widespread anxiety about the commercialisation and commodification of human tissue. The aims of this paper are: (a) to analyse some of these concerns, and (b) to see whether some of the main ethical arguments that lie behind them are sound. Part 1 looks at 'inducement arguments' against paying individuals for their tissue and concludes that these are generally quite weak. Part 2 examines some ethical objections to third parties (e.g. biotechnology companies and researchers) commercially exploiting human tissue. Firstly, it is argued that prospective tissue donors should be given very full information about the extent to which their tissues will be commercially exploited and about the financial interests of tissue collectors and researchers, since this is an essential component of valid consent. Secondly, some doubt is cast upon the (widely held) view that while 'the human body and its parts shall not, as such, give rise to financial gain', intellectual property based on human tissue research is generally acceptable ${ }^{1}$
\end{abstract}

\section{Introduction}

... the commercialization of human tissues ... raises a host of ... social, cultural, religious, and psychological issues on the meanings we assign to the human body and, in particular, on how we treat it during life and after death. Many people conceptualize the transfer of human organs and tissues during life or after death as a gift motivated by altruistic feelings, not economic incentives. They believe that the buying and selling of human biological samples debases the value of human life, is antithetical to the gift paradigm of tissue transfer, can lead to further oppression of the disenfranchised and the poor, and is an affront to the dignity of donors and their families. ${ }^{2}$

... the commodification of human cells, tissues and organs incites particular concern because boundaries usually assumed to be natural and inviolable are inevitably transgressed, raising concerns about 'self' and 'other', 'identity', 'genealogies', group continuity and so on. ${ }^{3}$

As these opening quotations suggest, there is considerable anxiety about the commercialisation or commodification of human tissue. My aims in this paper are (a) to analyse some of these concerns, and (b) to see whether the main ethical arguments and principles that lie behind them are sound. The expression 'human tissue' can be used very broadly but I will focus here mainly on the use of human tissue samples in biomedical research. Also, for reasons of space, I'll focus solely on tissue taken with consent from living competent adult donors. Taking tissue from dead bodies, from children, and from incompetent adults raises difficult additional ethical issues which

Genomics, Society and Policy, Vol.1 No.1 (2005) ISSN: 1746-5354

(C) CESAGen, Lancaster University, UK. 
can't be satisfactorily dealt with here. The commercial exploitation of human tissue raises a large number of ethical questions but, for our present purposes, the most pressing ones are: 'should research subjects be paid for their tissue?' and 'is there anything wrong with third parties (e.g. biotechnology companies) commercially exploiting human tissue?'. The remainder of this paper is divided into two parts, each dealing with one of these questions.

\section{[1] Should Individuals Be Paid For Their Tissue?}

According to the Medical Research Council (MRC):

... research participants should never be offered any financial inducement to donate samples. Payment of reasonable expenses or costs is however acceptable. ${ }^{5}$

This is very much the orthodox view and expressions of it are ubiquitous. For example, the Nuffield Council on Bioethics also tells us that:

Payment to donors of tissue should cover only reasonable expenses and should not act as an inducement ... [and] rewarded gifting is unacceptable...

In this part of the paper, I review some of the main arguments for this view, focussing in particular on the idea that payment, or excessive payment, may invalidate the consent of the tissue donor. I'll call this the Inducement Argument because the central idea is that payment may constitute an 'undue inducement' to take part in research.

In order for a consent to be valid, three main elements must be present (and present in sufficient quantities): information, competence and voluntariness. ${ }^{7}$ The Inducement Argument against paying tissue donors focuses mainly on the last of these, voluntariness. As the Nuffield Council on Bioethics puts it:

... [a] factor which may affect the voluntary nature of consent to research is any inducements accompanying invitations to participate in research. ${ }^{8}$

Although this is a widely held view, saying why we should believe it isn't easy. Here are some possible reasons. ${ }^{9}$

(a) Financial incentives encourage people to do things that they wouldn't otherwise do

(b) Financial incentives encourage people to do things that are likely to be harmful to them and which go against their 'better judgement'

(c) Financial incentives can be make people's actions and decisions less autonomous or non-autonomous. 
(a) and (b) seem to be what the General Medical Council has in mind when it instructs doctors:

... not [to] offer payments at a level which could induce research participants to take risks that they would otherwise not take, or to volunteer more frequently than is advisable or against their better interests or judgement $\ldots{ }^{10}$

(a) however seems problematic. For the fact that payments encourage people to do things that they otherwise wouldn't clearly doesn't, in and of itself, invalidate consent. For, if it did, then consent problems would be endemic and would occur every time someone was encouraged by payment to go to work for wages or to hand over property in return for a price. So while it can be conceded that some subjects wouldn't contribute tissue if it weren't for the money, this fact alone in no way invalidates their consent. $^{11}$

(b) is in some ways more plausible. Or at least it is plausible to suppose that we ought not to expose research subjects to more than a certain level of danger and ought not to encourage them, as the GMC puts it, to 'volunteer more frequently than is advisable'. Admittedly allowing payment (especially generous payment) does make it possible for there to be a class of 'professional' research subjects who expose themselves to excessive risk. ${ }^{12}$ The fundamental problem, though, is not payment per se but rather the fact that the subjects are exposed to too much danger. So provided that we could find a way of controlling the risk, perhaps through a licensing or registration scheme for research subjects, this worry about payment would not arise. Of course, there would inevitably be practical problems to overcome since would-be 'professional research subjects' may well try to subvert any safety systems put in place, but (in principle, at least) payment is not itself the primary problem.

This thought is bolstered by two further considerations. First, for any individual research project, the level of risk remains the same regardless of whether or not payment takes place. So if someone objects to paying subjects on the grounds that payment will encourage excessive risk-taking, she ought to object to the research project itself, not just the payment. An illuminating analogy is someone who objects to paying soldiers on the grounds that it encourages people to do something excessively dangerous. Surely we should say to such a person that, if the objection is excessive danger, then she should object to military service in general, not (just) to paid military service. Much the same goes for paying tissue donors. If the real worry is risk, we should object to dangerous research of all kinds, not just the paid variety.

Second, it is by no means obvious that monetary incentives make people act, as the GMC suggests, "against their better interests or judgement". Indeed, this is a rather surprising view to take since, in ordinary life, people are expected to trade off monetary gains and losses against other harms and benefits on a daily basis, and trading and employment require us constantly to do such reckoning. So if an adequately informed person decides, after deliberation, that it is worth subjecting herself to a certain risk in return for $£ 1000$ then we should not just assume that she is acting against her better judgement since, for all we know, the $£ 1000$ is more valuable to her than avoiding an $\mathrm{x} \%$ risk of physical harm. 
My impression is that sometimes what happens when we think about this issue is that we discount or ignore the prospective research subject's (often entirely sensible) desire for money, along with the (closely related) fact that having extra money will benefit her. This in turn leads us to think (mistakenly) that taking part in research is only in accordance with a person's "better interests or judgement" if she would have been willing to participate for free, or if doing so for free would be in his best interests. But this is a peculiarly demanding criterion to use, not least because it is not one that we would apply in any other context. After all, most people wouldn't go to work if it weren't for the pay but we don't generally say that, for this reason, wages make people act against their "better interests or judgement". Rather, we recognise that monetary gain must be counted as an important benefit to be weighed against the disbenefits of going to work (such as giving up one's free time). So I would recommend taking a similar approach to biomedical research and tissue donation.

Finally in Part 1, we need to look at the idea that financial incentives (above a certain level) can make people's decisions less autonomous. Again, the main idea is that certain sorts of payment, or payment in certain circumstances, exert 'undue influence on a participant's decision'. ' It's no accident that accusations of undue inducement almost always occur in one of two different contexts. The first is where the 'victim' of the inducement is in desperate need of money due to poverty, or because she has some special need - such as to purchase costly medical treatment. The second is where the 'victim' isn't in desperate need of money, but is offered such a huge amount of money to do $\mathrm{X}$ that doing $\mathrm{X}$ becomes almost irresistible. Let's call these 'desperate offeree' cases and 'enormous offer' cases. One notable thing that they have in common is that there's a huge gap between the offeree's level of welfare if she doesn't accept the offer, and her level of welfare if she does accept the offer. In desperate offeree cases, this is because the offeree needs what's offered and will be substantially harmed if she doesn't get it, while in enormous offer cases, it's because of the offer's sheer size. ${ }^{14}$

For our purposes, the important question is: is valid consent possible in desperate offeree cases and enormous offer cases? We should certainly concede immediately that in both scenarios it will usually be tremendously hard for offerees to decline what's on offer. However, consideration of the following example (from Wilkinson \& Moore) suggests that this isn't, in and of itself, a reason to think that autonomous and valid consent is impossible:

If the sole alternative to death is some lifesaving treatment, then one is unfree to turn it down, but this does not rule out autonomous choice of the treatment. All the features of autonomous choice might be present: careful deliberation, correct understanding of the options, no manipulation, and so on. If informed consent is possible, despite the dire choice one faces, it cannot be because one is free to refuse the treatment. It must be because one can nonetheless act autonomously. ${ }^{15}$

So, as Wilkinson \& Moore point out, even if we grant that there's a sense in which the recipients of enormous offers and desperate offerees aren't free to decline, this doesn't mean that they can't autonomously accept and validly consent. This must be so. Otherwise, it would be impossible for anyone ever to consent validly to lifesaving operations, not to mention lottery 'jackpot' wins or large salaries; the mere fact that a 
proposal is tremendously attractive clearly doesn't mean that it can't be validly and voluntarily accepted by the offeree.

Given this, the position as regards tissue is as follows. In many cases, the monetary rewards offered to tissue donors are relatively modest and the donors are not in any way 'desperate'. These cases are pretty unproblematic (in consent terms) provided that the other elements of valid consent (in particular, adequate information and competence) are in place. There may however be a few cases which fall into the desperate offeree and/or enormous offer categories outlined above: cases in which the prospective tissue providers are significantly economically disadvantaged and/or where the rewards are unusually large. In some of these cases, it may be legitimate to ask whether the consent is truly voluntary. ${ }^{16}$ But, as the lifesaving treatment and similar examples show, valid consent is not only possible in such cases, it would appear to be the norm. So even in the 'worst case scenario' (where a large payment is offered to an impoverished research subject) it will usually be possible for the person to consent autonomously and voluntarily to selling her tissue. And so what was earlier labelled argument (c) would appear to be very weak.

In Part 1, we've reviewed a particular set of arguments against paying people for supplying tissue for research purposes. Each one of these is a version of the Inducement Argument and seeks to establish that monetary incentives should be avoided because they are likely to invalidate consent. For the reasons outlined above, we should conclude that these arguments are quite weak. This doesn't on its own count decisively in favour of permitting payment since there may well be other objections that are nothing to do with consent. But we have at least seen that the case against payment is not as strong as it at first appears, especially since (as Anderson and Weijer point out) consent and voluntariness objections are amongst those most commonly raised in the extant ethics literature:

To the extent that the practice of paying research subjects for study participation has been examined in the literature to date, critical reflection has focused on questions related to the voluntariness of consent when subjects are paid, and the injustice of preferential enrolment of the poor in studies that pay subjects. $^{17}$

They also mention 'the injustice of preferential enrolment of the poor' and this would be a fruitful area to explore in search of alternative objections to payment. ${ }^{18}$ That said, my own view (argued for elsewhere) is that such arguments usually turn out to be unsuccessful, not (of course) because exploiting economically disadvantaged people is acceptable, but because they generally apply equally to a very wide range of commercial practices, not just against commerce in human tissue. ${ }^{19}$ In other words, they fail to single out for especially restrictive treatment or condemnation the commodification of the human body, as opposed to commodification in general, which could include the whole of what is sometimes called 'capitalism'.

Genomics, Society and Policy, Vol.1 No.1 (2005) ISSN: 1746-5354

(C) CESAGen, Lancaster University, UK. 


\section{[2] Commercial Exploitation By Third Parties}

As Bauer, Taub and Parsi point out, the commercialisation of human tissue, or at least the commercialisation of research using human tissue, is potentially beneficial in a number of ways:

For industry, the likelihood of profit based on medical products derived from human tissues is an effective incentive to invest in related academic research. With the judicious use of patents and other forms of intellectual property rights, industry has added reason to support cutting-edge and sometimes financially risky academic research involving human tissues. From the perspective of academic centers, the infusion of capital by industry can help to fund innovative research and support the training of researchers. Perhaps the most important benefit associated with the commercialization of human tissue comes from the successful interchange between the two spheres, toward a more efficient transmission of knowledge from academic based tissue banks to industry, facilitating the development and delivery of medical products to the public. $^{20}$

This view is backed up by the MRC:

The development of new drug therapies, and diagnostic and screening tests, to the point where they can be made sufficiently widely available to benefit human health, is crucially dependent on commercial involvement. Therefore access by the commercial sector to samples of human material collected in the course of MRC-funded research should be facilitated, where this is consistent with our mission. ${ }^{21}$

So there is a fairly strong prima facie case for (at least some forms of) commercialisation and, in this part of the paper, I ask whether there is anything morally wrong with third parties (e.g. academic researchers or biotechnology companies) commercially exploiting human tissue?

Human tissue can be commercially exploited in countless ways. Nonetheless, it is useful to draw a distinction between three main categories of commercial activity. First, and most straightforwardly, a researcher (or other tissue gatherer) could simply sell a physical tissue collection, or part of it, for profit. Second, tissue banks could sell services to researchers, such as limited access to a tissue collection, or the provision of data about a tissue collection. Finally, one might base intellectual property rights (including, but not just, 'DNA patenting') on research involving human tissue.

Applying to all of these categories is a further distinction between 'consent issues' and issues which (arguably) persist even when valid consent has been obtained. The most obvious consent issues arise when no consent for tissue donation has been obtained or, more commonly, when questions are raised about the information available to the donor at the time when she consented. In particular, was she aware, when she consented, that her tissue would be used for commercial purposes and, if not, ought she to have been made aware of this as part of the informed consent 
process? On this point, the GMC gives the following advice to doctors engaged in research:

14. You must be open and honest in all financial and commercial matters relating to your research and its funding. In particular you must: declare to research ethics committees, prior to the research being approved, all financial interests and sums of money which you know, or estimate, will be paid for the research undertaken; accept only those payments and benefits approved by the research ethics committee; give participants information on how the research is funded, including any benefits which will accrue to researchers and/or their departments; respond honestly and fully to participants' questions, including inquiries about direct payments made to you and any financial interests you have in the research project or its sponsoring organisations ...

24. ... Where material is being obtained for a specific project, you must explain how the sample will be used; where a sample is to be stored and used in further research projects, this must be made clear. You must be prepared to respond honestly and sensitively to any questions which the participants may ask.

25. You must be open and honest about any financial transactions associated with the use of tissues, organs or body fluids ... ${ }^{22}$

This looks like a 'gold standard' approach as far as the financial interests of doctorresearchers are concerned. Research subjects and research ethics committees must be told pretty much everything about the uses to which donated tissue will be put and about the financial interests of researchers. However, the GMC guidelines don't (not least because of the GMC's particular remit) impose constraints on the behaviour of other organisations further 'downstream'. Hence, for example, a doctor-researcher might (with the consent of the research ethics committee and the research subject) pass tissue to a third party for only a modest payment covering 'administrative costs', only for that third party to use the tissue in a highly 'commercial' way later on.

The MRC advises us that:

Research participants may be particularly sensitive to the idea of a company or an individual making a profit out of research material that they have freely donated. It is important that research participants are made aware of the potential benefits of allowing commercial access, and that the role of any one individual's sample in the generation of future profits is likely to be minimal as well as impossible to quantify. Given the possible sensitivities, it is essential that research participants know that their sample or products derived from it may be used by the commercial sector, and that they will not be entitled to a share of any profits that might ensue. ${ }^{23}$

The GMC-MRC orthodoxy then is that tissue donors should, as part of the consent process, be told: (a) that access to their donated tissue by commercial organisations is possible or likely; (b) about the financial interests of the researchers; and (c) that they will not themselves get a share of any profits. ${ }^{24}$ It does look then as if adhering to their standards will be sufficient to deal with most consent issues relating to 
commercialisation. For the basic idea, a simple one, is that if prospective tissues donors are warned in advance that commercial exploitation might take place (and that they don't stand to profit) then they can opt out and not give their tissue if they are unhappy with that arrangement. What is to be avoided above all else, since it would (as the MRC puts it) 'damage the gift relationship', is giving people false expectations about what will happen to their tissue.

Having made a distinction between 'consent issues' and issues which (arguably) persist even when valid consent has been obtained, I want to turn now to the latter, and to ask: assuming the presence of valid consent, is there anything wrong with a third party's commercially exploiting human tissue samples? Again, the GMC-MRC guidance is a good starting point. The GMC tells doctors that:

Financial remuneration for supplying [tissues, organs or body fluids] to other organisations or individuals should be limited to administrative costs involved, and you should not be involved, directly or indirectly, in buying or selling human organs, tissues or body fluids. ${ }^{25}$

While the MRC tells its researchers that:

The human body and its parts shall not, as such, give rise to financial gain. Researchers may not sell for a profit samples of human biological material that they have collected as part of MRC funded research ... [but i]ntellectual property rights (IPR) arising from research using human samples may be sold or licensed in the same way as other IPR. ${ }^{26}$

The idea that 'the human body and its parts shall not, as such, give rise to financial gain' is a commonplace one and this form of words can be found in Article 21 of the Council of Europe's Oviedo Convention. ${ }^{27}$ Clearly, the 'as such' is crucial for the MRC which (like many writers on this subject) posits an important ethical boundary between, on the one hand, selling body parts (as in, for example, the human kidney trade) and, on the other, owning and selling intellectual property in inventions which are based on human tissue research. In the remainder of this paper I review two arguments for this distinction. ${ }^{28}$ The first says that while buying and selling physical human tissue involves (or is likely to involve) wrongfully treating human bodies as mere commodities or objects, this is not true (or is less likely to be true) of commercially exploiting inventions based on human tissue research. The second says that permitting researchers to have intellectual property rights in inventions based on human tissue research is a fair way of recognising and rewarding their creative endeavour, while this is not true of merely trading physical human tissue (which involves little or no creative endeavour).

The first argument relies on two premises: that we ought not to treat human body parts or tissues as mere objects or commodities (that we ought not to objectify or commodify them); and that buying and selling body parts or tissues would involve objectification and/or commodification.

The term 'objectification', when used in this debate, is almost always used as a negative moral concept. In other words, 'objectification' is taken to mean 'wrongful

Genomics, Society and Policy, Vol.1 No.1 (2005) ISSN: 1746-5354

(C) CESAGen, Lancaster University, UK. 
objectification'. But what particular kind of wrong is objectification? Not surprisingly, to objectify is to treat as a mere object. However, treating objects as objects doesn't count as objectification. Rather, to objectify is to treat as a (mere) object something which isn't really an object. As Nussbaum puts it:

Treating things as objects is not objectification, since ... objectification is making into a thing, treating as a thing, something that is not really a thing. ${ }^{29}$

Similar considerations apply to 'commodification'; to 'commodify' (in the moral sense) is to treat as a (mere) commodity something which isn't really a commodity (and so arguably we couldn't, in the moral sense, commodify baked beans or coal). ${ }^{30}$

When discussing objectification, and connected concepts such as commodification, it is always worth reminding ourselves of something which is obvious and yet sometimes overlooked in discussions of the commercialisation of the body: the fact that bodies and body parts are physical objects. Hence, any ethical concerns that we have about the objectification of bodies can't be about whether bodies are treated as objects, since they are objects. Rather, our concerns must be about whether bodies are treated as mere objects. So the crucial question is: what does 'mere' mean here? Or, to put it another way, what might bodies be over and above physical objects? What is treating a body as a mere object to be contrasted with? There seems only to be one remotely plausible answer to this. Bodies are more than mere objects insofar as they are somehow intimately related to persons. ${ }^{31}$

So to objectify the body is to treat it as a mere object and this means treating it as if it weren't intimately related to a person. But what is it to treat human tissue, or a human body, as if it isn't intimately related to a person? In practical terms, consent and harm will be vitally important. For two of the main ways of treating a human body as a mere object are: (a) doing something to it without requiring the person's valid consent, and (b) doing something to it which will harm the person. Indeed, while there isn't space to argue the point here, I would go further and suggest that the following moral principle is true: A does not objectify B by doing $\mathrm{x}$ to B's body provided that (i) A requires B's valid consent to do $\mathrm{x}$ and wouldn't do $\mathrm{x}$ without B's valid consent and (ii) $\mathrm{x}$ is not substantially harmful to B and A wouldn't do x to B if she believed it to be substantially harmful to $\mathrm{B}^{32}$

This view of objectification has some direct implications for the issue at hand. In particular, what we are presently looking at is the question of whether there is anything wrong with a third party's commercially exploiting human tissue samples when valid consent is present? So we already know, ex hypothesi, that consent isn't a problem in the cases under consideration. This just leaves us with the harm issue: more specifically, the question of whether selling a donor's tissue for profit would harm her even in cases where she had consented. In answer to this we should certainly concede that harm is possible. For example, personal information about the donor could inadvertently be released in unfavourable circumstances, or the output of the research might harm society in ways that adversely impact on the donor. However, almost all of the foreseeable harms would seem to arise not because of 
commercialisation per se, but just because the research was carried out, or because tissue samples were transferred (whether for profit or not).

It seems therefore that the risk of wrongful objectification will be minimal in the cases under discussion because: (a) we already know, ex hypothesi, that consent isn't a problem, and (b) harm to the donor will be extremely unlikely and/or not caused by commercialisation per se. Of course, wrongful objectification is a very real prospect in cases where the GMC-MRC consent guidelines are not followed, but this is an argument for following the consent guidelines, not a wider anti-commercialisation argument.

Let's turn now to the second and final argument which, for reasons that will become clear in a moment, I'll call the Neo-Lockean Argument. This says that permitting researchers to have intellectual property rights in inventions based on human tissue research is a fair way of recognising and rewarding their creative endeavour, but this is not true of merely trading physical human tissue which involves little or no creative endeavour. An important distinction between tangible and intellectual property underlies the Neo-Lockean Argument. ${ }^{33}$ For our present purposes, tangible property is physical human tissue, and this is to be contrasted with (for example) data sets concerning human tissue collections or patents on biotechnological inventions, both of which are intellectual property. With this distinction in place, the argument says that, although certain kinds of intellectual property in the human body are acceptable because they fairly reward researchers for their creative efforts, simply owning and trading body parts and tissues cannot be justified in this way, because these are natural resources.

Underlying this is the Locke's idea that property rights are justified principally by the extent to which someone's labour has been 'mixed' with a natural resource. Locke tells us that:

Whatsoever then he removes out of the state that nature hath provided, and left it in, he hath mixed his labour with, and joined to it something that is his own, and thereby makes it his property. It being by him removed from the common state nature hath placed it in, it hath by this labour something annexed to it, that excludes the common right of other men: for this labour being the unquestionable property of the labourer, no man but he can have a right to what that is once joined to, at least where there is enough, and as good, left in common for others. ${ }^{34}$

According to the Neo-Lockean Argument, this entails that tangible property in human tissue isn't justified, since human tissue is a naturally occurring resource which is simply gathered by the researcher. There is no 'mixing' of labour and the resource, simply the appropriation of the resource. Intellectual property in biotechnological inventions however can be justified even when based on human tissue, because the researcher 'mixes her labour' with the tissue. 
This Neo-Lockean Argument though is problematic, chiefly because the distinction between cases in which tissue is merely appropriated and cases in which it is 'mixed with' the researcher's labour is not clear-cut. The most obvious difficulty is that even someone who just gathers and banks tissue is mixing her labour with it. Indeed, modern tissue gathering and banking, if it is to be done well, requires substantial effort, skill, and investment. So, even if we concede that tissue banking generally requires less labour than creating new biotechnological inventions, it is nonetheless clear that it requires some labour, often quite considerable amounts, and so it looks as if tissue bankers and gatherers will meet Locke's criterion for property rights. Tissue banking is (in some respects) akin to fishing and hunting and, as Locke himself points out, such activities generally involve labour in ways that justify property claims. In other words, fisherman and hunters are generally entitled to own and sell what they acquire, even though they didn't create or invent it, because of the labour involved in the harvesting process. ${ }^{35}$

At this point, it may be objected that an important difference between gathering human tissue and fishing is that, while human tissue is gifted by individual donors, fish are simply taken from a common stock (if we restrict ourselves to cases in which the fish and water are not privately owned, that is). So perhaps this, the fact that it is a gift, can account for the (alleged) wrongness of 'selling on' human tissue.

Certainly talk of 'gifting' and 'the gift relationship' is ubiquitous in ethical debates about the commodification of human tissue. ${ }^{36}$ However, I doubt whether citing 'the gift relationship' will do much to help the Neo-Lockean Argument. This is, firstly, because banking gifted tissue doesn't require any less labour on the part of the banker than banking tissue acquired in other ways. Indeed, acquiring gifted tissue may well be more labour-intensive than the main alternatives because of the time spent obtaining informed consent from the donors. So the fact that tissue is 'gifted' doesn't seem to make much difference as far as the Neo-Lockean labour-criterion for property rights is concerned. Secondly, we should remember that the fact that someone gives a thing to someone else as a gift isn't, in and of itself, a reason for the recipient not to then sell that thing to a third party. Rather, the moral status of 'selling on' depends on specific features of the original giving. In particular, did the original gift come with the giver's consent for onward sale, did it come with any conditions or 'strings' attached, and would 'selling on' hurt the giver's feelings? We cannot infer from the bare fact that something is a gift that it cannot be sold on, and there are lots of gift situations in which it is understood from the outset that 'selling on' will take place: for example, when people give their clothes to charity shops for resale, or donate their empty bottles to commercial companies for recycling. There's no reason why tissue donation can't be modelled on these, generally rather benign, practices. 'Selling on' gifts may of course be objectionable when the giver doesn't expect it and is hurt or offended by it (for example, if I were to sell off all my birthday presents, my friends and relatives might, with some justification, take offence and think that I had acted badly). But, as we saw earlier, this kind of issue can really be dealt with by having adequate informed consent procedures at the outset and by following the GMC-MRC guidelines (or something similar). In particular, as the MRC puts it: 'it is essential that research participants know that their sample or products derived from it may be used by the commercial sector'. ${ }^{37}$ 
Finally it is worth noting that, even if the above criticisms of the Neo-Lockean Argument are unsound, the argument still might not support a very clear-cut moral distinction between intellectual and tangible property. This is because certain forms of intellectual property, in particular those 'DNA patents' which are very closely related to naturally occurring substances, might themselves be legitimate targets for the Neo-Lockean Argument. For, it has been argued, some such patents merely appropriate what already exists in nature in the same way that physical tissue gatherers (allegedly) do. Indeed, DNA patent holders, it could be argued, fall foul of Neo-Lockean principles to an even greater extent than physical tissue gatherers, since the former not only collect but also try to monopolise natural resources and to stop others from using them via patent rights. Clearly, there is much more to be said about the whole subject of 'DNA patenting'. Nonetheless, it is worth keeping in mind that intellectual property based on human tissue research is itself a controversial and difficult topic, quite possibly more so than the ownership and sale of physical tissue. ${ }^{38}$

\section{Conclusions}

In Part 1, we saw that the case against paying research subjects for their tissue is not as strong as it at first appears. In Part 2, we moved on to look at third party commercial exploitation of human tissue by (for example) researchers, tissue banks, and biotechnology companies. Two main conclusions emerged. Firstly, there was broad support for the 'orthodox' view of informed consent expressed by, amongst others, the GMC and MRC. Roughly, this says that prospective tissue donors should be given very full information about the extent to which their tissue will be commercially exploited and about the financial interests of the tissue gatherer/researcher. Secondly, some scepticism was expressed about another widely held view: the idea that while 'the human body and its parts shall not, as such, give rise to financial gain', intellectual property based on human tissue research is generally acceptable. ${ }^{39}$ It was argued that some of the main ethical objections to owning and trading physical human tissue are unconvincing and/or that they apply equally to tangible and intellectual property. None of this counts decisively in favour of permitting the widespread commercialisation of human tissue, but (as with Part 1) we have seen that the 'anti-commercialisation' arguments are perhaps not as strong as they at first appear.

\footnotetext{
${ }^{1}$ Council of Europe. 1997. Convention for the Protection of Human Rights and Dignity of the Human Being with Regard to the Application of Biology and Medicine (CETS 64).

${ }^{2}$ K Bauer, S. Taub, \& K. Parsi. Ethical Issues in Tissue Banking for Research: a brief overview of existing organization policies. Theoretical Medicine 2004; 25; 113-142 [p. 128]

${ }^{3}$ M. Lock. The Alienation of Body Tissue and the Biopolitics of Immortalized Cell Lines. Body \& Society 2001; 7; 63-91 [p.65]

${ }^{4}$ Like Wilkinson \& Moore, I prefer the term 'subjects' to 'participants' The latter term is ambiguous between researchers and research subjects. Furthermore, only some kinds of research require the subjects' participation. M. Wilkinson \& A. Moore. Inducement in Research. Bioethics 1997; 11; 373 389. [p.373]

${ }^{5}$ MRC (Medical Research Council). 2001. Human Tissue and Biological Samples for Use in Research: 3 .

${ }^{6}$ Nuffield Council on Bioethics 1995. Human Tissue: ethical and legal issues: vi.

${ }^{7}$ R. Faden \& T. Beauchamp. 1994. The Concept of Informed Consent In Contemporary Issues in Bioethics. T. Beauchamp \& L. Walters, eds. Belmont, CA: 149. R. Gillon. 1986. Philosophical
}

Genomics, Society and Policy, Vol.1 No.1 (2005) ISSN: 1746-5354

(C) CESAGen, Lancaster University, UK. 
Medical Ethics. Chichester. Wiley: 113. S. Wilkinson. 2003. Bodies for Sale. London. Routledge: 76.

${ }^{8}$ Nuffield Council on Bioethics. 2002. The Ethics of Research Related to Healthcare in Developing Countries: 76.

${ }^{9}$ Another related reason, not discussed here due to lack of space, is that some offers of monetary reward can be coercive. For a full discussion of this argument see: S.Wilkinson, op. cit. 6, pp. 82-98 \& 116-129.

${ }^{10}$ GMC (General Medical Council). 2002. Research: the role and responsibilities of doctors: s.14.

${ }^{11}$ See: Nuffield Council on Bioethics, op. cit 7, pp. 78-9.

${ }^{12}$ For an interesting illustration of this problem see: R. Boyd. A view from the man in the seat opposite. BMJ 1998; 317; 410.

${ }^{13}$ Nuffield Council on Bioethics, op. cit 7, p.14.

${ }^{14}$ S.Wilkinson, op. cit. 6, pp. 116-26.

${ }^{15}$ Wilkinson \& Moore, op. cit 3, p. 377.

${ }^{16}$ Distinguishing between those cases in which there's a 'voluntariness problem' and those in which there's not will however be difficult. S.Wilkinson, op. cit. 6, pp. 75-97, 105, \& 116-26.

${ }^{17}$ J. Anderson \& C. Weijer. The Research Subject as Wage Earner. Theoretical Medicine 2002; 23; 359-376. [p.359]

${ }^{18}$ See: Nuffield Council on Bioethics, op. cit 7. S.Wilkinson, op. cit. 6, pp. 9-26 \& 130-2.

${ }^{19}$ B. Brecher. The Kidney Trade: Or, the Customer Is Always Wrong. Journal of Medical Ethics 1990; 16; 120-123. Brecher, B. Organs for Transplant: Donation or Payment? In R. Gillon, ed. Chichester. John Wiley \& Sons: 993-1002. S. Wilkinson \& E Garrard. Bodily Integrity and the Sale of Human Organs. Journal of Medical Ethics 1996; 22; 334-339. S. Wilkinson. The exploitation argument against commercial surrogacy. Bioethics 2003; 17; 169-187. S.Wilkinson, op. cit. 6 .

${ }^{20}$ Bauer et al, op. cit 1, p. 114.

${ }^{21}$ MRC, op. cit, 4, p. 12.

${ }^{22}$ GMC, op. cit 9.

${ }^{23} \mathrm{MRC}$, op. cit, 4, p. 12.

${ }^{24}$ The question of whether donors should get a share of any profits is another interesting issue that can't be discussed here owing to lack of pace.

${ }^{25}$ GMC, op. cit 9, s. 25.

${ }^{26}$ MRC, op. cit, 4, p. 3.

${ }^{27}$ Council of Europe. 1997. Convention for the Protection of Human Rights and Dignity of the Human Being with Regard to the Application of Biology and Medicine (CETS 64). It should be noted that the UK is not a signatory to this treaty.

${ }^{28}$ A further argument for this distinction, which there isn't space to review here, says that permitting researchers to have intellectual property rights in inventions based on human tissue research will have generally beneficial effects by incentivising research and development, whereas this is not true of allowing the trading of the physical tissue itself. For further discussion of this complex empirical issue see for example: M. Heller and R. Eisenberg. Can Patents Deter Innovations? The anti-commons in biomedical research. Science 1998; 280; 698-701. D. Resnik. DNA Patents and Scientific Discovery and Innovation: assessing benefits and risks. Science and Engineering Ethics 2001; 7; 29-62. S.Wilkinson, op. cit. 6, pp. 199-206.

${ }^{29}$ M. Nussbaum. Objectification. Philosophy and Public Affairs 1995; 24; 249-291. [p. 257]

${ }^{30} \mathrm{~S}$. Wilkinson. Commodification Arguments for the Legal Prohibition of Organ Sale. Health Care Analysis 2000; 8; 189-201. S.Wilkinson, op. cit. 6, pp. 27-55.

${ }^{31}$ The expression 'somehow intimately related to persons' is meant to be metaphysically innocent and is not meant to imply any form of dualism, since one of the possible relations between persons and their bodies is identity.

32 This is a rather cautious formulation of a principle that provides sufficient conditions for nonobjectification. It may be that less cautious versions are also true (e.g. perhaps requiring valid consent is enough for non-objectification). If they are, then this will provide further support for the argument advanced here. See: S.Wilkinson, op. cit. 6, pp. 27-55 \& 72-81.

${ }^{33}$ For further explanation of this distinction see: S.Wilkinson, op. cit. 6, pp. 183-7.

${ }^{34}$ J. Locke. 1690. Second Treatise of Government: s. 27-8.

${ }^{35}$ Ibid.

Genomics, Society and Policy, Vol.1 No.1 (2005) ISSN: 1746-5354

(C) CESAGen, Lancaster University, UK. 
${ }^{36}$ The work standardly cited in connection with this point is R. Titmuss. 1970. The gift relationship: from human blood to social policy. London. Allen and Unwin.

${ }^{37} \mathrm{MRC}$, op. cit, 4, p. 12.

${ }^{38}$ For further discussion see: L. Andrews and D. Nelkin. 2001. Body Bazaar: the market for human tissue. New York. Crown. Nuffield Council on Bioethics. 2002. The Ethics of Patenting DNA: a discussion paper. D. Resnik. The Morality of Human Gene Patents. Kennedy Institute of Ethics Journal 1997; 7; 43-61. S. Wilkinson. Intellectual Property Rights and the Human Body: is 'gene patenting' a special case?. Imprints $2001 ; 5 ; 132-160$. S.Wilkinson, op. cit. 6, pp. 83-245.

${ }^{39}$ Council of Europe, op. cit. 26. 